\title{
Cotton gauze bandage: a support for protease immobilization for use in biomedical applications
}

\author{
Inês José Seabra ${ }^{1,2, *}$, Maria Helena Gil ${ }^{2}$ \\ ${ }^{1}$ Departamento de Ciência e Tecnologia Alimentar, Escola Superior Agrária, Instituto Politécnico de Coimbra, \\ ${ }^{2}$ Departamento de Engenharia Química, Faculdade de Ciências e Tecnologia, Universidade de Coimbra
}

*Correspondence:

I. J. Seabra

Departamento de Ciência e

Tecnologia Alimentar]

Escola Superior Agrária

Instituto Politécnico de Coimbra

3040-316 - Becanta - Portugal

E-mail: iseabra@esac.pt
The covalent immobilization of trypsin on sterilized cotton gauze bandage was carried out for future use as an anti-inflammatory agent on wound dressing. The optimal immobilization conditions were determined: the influence of $\mathrm{pH}$, concentration, and volume of the trypsin solution used in the immobilization procedure was studied. The catalytic properties and kinetic parameters, as well as the storage stability of the immobilized and free enzyme were compared. Results showed that the optimal $\mathrm{pH}$ and temperature for the immobilized trypsin in the hydrolysis of N-benzoyl-DLarginine p-nitroanilide were 9.5 and $55^{\circ} \mathrm{C}$, which were higher than those of the free form $\left(7.5\right.$ and $\left.45^{\circ} \mathrm{C}\right)$. It was found, at $37^{\circ} \mathrm{C}$ and pH 7.0 (approximately, the physiological conditions), that the $K_{m}$ (Michaelis constant) was $3.98 \mu \mathrm{mol} / \mathrm{mL}$ and that $V_{\max }$ (maximal reaction rate) was $0.719 \mu \mathrm{mol} /(\mathrm{min} \mathrm{mg})$ for the immobilized trypsin, compared to a $K_{m}$ of $2.46 \mu \mathrm{mol} / \mathrm{mL}$ and $a V_{\max }$ of 2.89 umol/(min mg) for the free trypsin. The amount of immobilized trypsin was $6 \mathrm{mg} / \mathrm{g}$ dried support. After 30 days, no trypsin had liberated from the support. The superior performance of the immobilized trypsin demonstrates its potential application in practice.

\section{INTRODUCTION}

Enzymes are specific biocatalysts, and so, they should be perfect therapeutic agents. However, their regular clinical applications are still limited by many factors, such as high price, fast inactivation in physiological conditions, and high sensibility towards the action of endogenous proteases and natural inhibitors. These factors can decrease their activity.

\section{Uniterms}

- Cotton gauze bandage

- Trypsin/Immobilization

- Cutaneous wound/ treatment
Enzyme immobilization can overcome these limitations. By mimicking the natural form of occurrence in living cells, where enzymes for most of the cases are attached to cellular membranes, the immobilization stabilizes the enzymes' structure and, hence, their activities.

The properties of immobilized enzymes are governed by the properties of both the enzyme and the support material (Kennedy, Cabral, 1987). Medical requirements 
considerably limit the number of natural or synthetic supports that can be used in the immobilization of enzymes for therapeutic uses. The supports have to be highly pure, should not cause allergenic or carcinogenic effects in human body, or lead to the formation of toxic products during its biodegradation, and should be completely removed or metabolized after performing their therapeutic function.

In this study, cotton gauze bandage was chosen to immobilize an enzyme with anti-inflammatory properties, for use in wound healing therapy. Cotton is $85-90 \%$ cellulose (Scott, Roff, 1971) and is abundant in nature. Chemically, cellulose is composed of $\beta(1 \rightarrow 4)$ glucose units, forming a long chain linear polymer. Chemical reactivity and physical properties of cellulose and its derivatives depend on the treatment which they have been subject to (Stevens, 1990). Different enzymes have been attached to fibers, membranes and to gels of cellulose or cellulose derivatives (Gemeiner et al., 1993). Cellulose acetate, cellulose butyrate, ethyl cellulose (Gil et al., 1996) and poly(hydroxyethylacrylate)co-cellulose (Beddows et al., 1984) can be given as examples of cellulose derivatives that were used for the immobilization of urease and trypsin, respectively.

Trypsin was the model proteolytic enzyme chosen for the immobilization, since it is highly efficient and has been described as specific for catalyzing the breakdown of peptide linkages (Kunitz, Northrop, 1936). Besides, this enzyme has been successfully used, when immobilized on a synthetic polymer, to cure inflammation in medical treatment (Watanabe et al., 1988).

\section{MATERIAL AND METHODS}

\section{Material}

Trypsin from bovine pancreas (EC3.4.21.4) in a powder form, and N-benzoyl-DL-arginine p-nitroanilide (BAPNA) were obtained from Sigma. The sterilized (100\%) cotton gauze bandage $5 \mathrm{~cm} \times 500 \mathrm{~cm}$ was purchased from a local pharmacy. All other chemicals used were of analytical grade.

\section{Immobilization of trypsin on cotton gauze bandage}

Trypsin was covalently attached to the sterilized cotton gauze bandage. It was necessary to produce aldehyde groups on the cellulose chain, via periodate reaction, for subsequent linkage of the trypsin. The activation procedure was as follows: $5 \mathrm{~cm} \times 5 \mathrm{~cm}$ gauze pieces were treated with $0.1 \mathrm{M}$ sodium periodate solution for $18 \mathrm{~h}$ in the dark, at ambient temperature (Carneiro-daCunha et al., 1999) and, then, thoroughly washed with distilled water. These gauze pieces and the trypsin solution (prepared with a buffer solution) were incubated, at $4{ }^{\circ} \mathrm{C}$, for $18 \mathrm{~h}$ and, finally, washed with physiological solution, until the washing solution was free of trypsin, which was confirmed with a spectrophotometric assay at $\lambda 280 \mathrm{~nm}$ (Spectrophotometer UV/VIS JASCO 7800).

To optimize the preparation of trypsin, the effect of the following basic factors of the applied immobilization procedure on the activity of the trypsin-gauze system was studied: $\mathrm{pH}$, concentration, and volume of trypsin solution. The study was performed in such a way that a chosen factor of the procedure under examination was changed while the remaining factors were kept fixed.

\section{Trypsin activity assay}

Catalytic activities of free and immobilized trypsin were determined by measuring the amount of $p$-nitroaniline (spectrophotometrically, at $\lambda 410 \mathrm{~nm}$ ) liberated from the trypsin-catalyzed hydrolysis of BAPNA, using a discontinuous assay (Gil, 1983).

Specific activities were expressed in $\mu \mathrm{mol}_{\mathrm{p} \text {-nitroaniline }}{ }^{\prime}$ $\left(\min \mathrm{mg}_{\text {trypsin }}\right)$ for free and immobilized enzyme.

Unless otherwise stated, reactions were carried out in a $0.1 \mathrm{M}$ phosphate buffer solution, at $\mathrm{pH} 7.0$ and $37^{\circ} \mathrm{C}$ (approximately, the physiological conditions), in a water bath.

\section{Quantity of immobilized protein}

Since trypsin has $15 \%$ nitrogen by weight (Green, Neurath, 1953), the amount of immobilized trypsin (in optimal conditions) was estimated by Elementar Analysis (Elementar Analyser 1108 CHNS-O). Six gauze pieces were triturated - one with no trypsin (to assure that the membrane had no nitrogen) and five with the immobilized enzyme - and $2 \mathrm{mg}$ of each were analyzed.

\section{Determination of physico-chemical properties of free and immobilized trypsin}

\section{Effect of $\mathrm{pH}$ on enzyme activity}

The dependence of enzyme activity on $\mathrm{pH}$ was investigated in buffer solutions with $\mathrm{pH}$ values ranging from 5.5 to 8.6 , for free trypsin, and from 5.0 to 10.5 , for immobilized trypsin, at $37^{\circ} \mathrm{C}$. Buffer solutions used are indicated in Table I.

\section{Effect of temperature on enzyme activity}

The effect of temperature on enzyme activity was studied between 10 and $65^{\circ} \mathrm{C}$, for free trypsin, and 10 and $77^{\circ} \mathrm{C}$, for immobilized trypsin, at $\mathrm{pH}$ 7.0. 
TABLE I - Buffer solutions used in experimental work

\begin{tabular}{ll}
\hline Buffer $\mathrm{pH}$ & Reagents \\
\hline $5.0-5.4$ & $\mathrm{NaOAc} 0.1 \mathrm{M}+\mathrm{HOAc} 0.1 \mathrm{M}$ \\
$5.5-7.9$ & $\mathrm{Na}_{2} \mathrm{HPO}_{4} 0.1 \mathrm{M}+\mathrm{NaH}_{2} \mathrm{PO}_{4} 0.1 \mathrm{M}$ \\
$8.2-8.9$ & $\mathrm{Na}_{2} \mathrm{~B}_{4} \mathrm{O}_{7} .10 \mathrm{H}_{2} \mathrm{O} 0.025 \mathrm{M}+\mathrm{HCl} 0.1 \mathrm{M}$ \\
$9.2-10.5$ & $\mathrm{Na}_{2} \mathrm{~B}_{4} \mathrm{O}_{7} .10 \mathrm{H}_{2} \mathrm{O} 0.025 \mathrm{M}+\mathrm{NaOH} 0.1 \mathrm{M}$ \\
$11.0-11.8$ & $\mathrm{Na}_{2} \mathrm{HPO}_{4} 0.05 \mathrm{M}+\mathrm{NaOH} 0.1 \mathrm{M}$ \\
$12.0-13.0$ & $\mathrm{KCl} 0.2 \mathrm{M}+\mathrm{NaOH} 0.2 \mathrm{M}$ \\
\hline
\end{tabular}

Kinetic parameters $K_{M}$ and $V_{\max }$

Constant amounts of free and immobilized trypsin were subjected to reaction of BAPNA hydrolysis in solutions of increasing BAPNA concentration. For each experiment, the initial rate of reaction was measured, using a discontinuous assay.

\section{Trypsin leakage from the support}

In order to study the trypsin leakage from the support, four gauze-immobilized trypsin samples were stored, for 30 days, in $10 \mathrm{~mL}$ of physiological solution. Protein concentration in the solution was determined spectrophotometrically, at $\lambda 280 \mathrm{~nm}$.

Storage stability at $4^{\circ} \mathrm{C}$ and $25^{\circ} \mathrm{C}$

To evaluate storage stability at $4{ }^{\circ} \mathrm{C}$, three types of samples were prepared: trypsin solution $(1.5 \mathrm{mg} / \mathrm{mL})$ in $0.1 \mathrm{M}$ phosphate buffer $\mathrm{pH}$ 7.0, gauze-immobilized trypsin samples stored wet in physiological solution, and gauze-immobilized trypsin samples stored in a dry form. All samples were stored at $4{ }^{\circ} \mathrm{C}$. Their activities were assayed periodically, during 50 days.

The same type of trypsin samples were used to study storage stability at $25^{\circ} \mathrm{C}$. All samples were stored in a water bath. Activities of samples newly taken from the storage were assayed periodically, during 30 days.

\section{Reusability}

Two types of reusability assays were performed: one sample of gauze-immobilized trypsin was stored in physiological solution, the other one dry, both at $4{ }^{\circ} \mathrm{C}$. Activities of samples were measured several times during 30 days. After each activity determination, samples were washed with physiological solution and left stored till the next assay (the first sample in solution and the other one dry).

\section{RESULTS AND DISCUSSION}

The proposed method of immobilization of trypsin on cotton gauze bandage involves the reactions represented in the following figures.

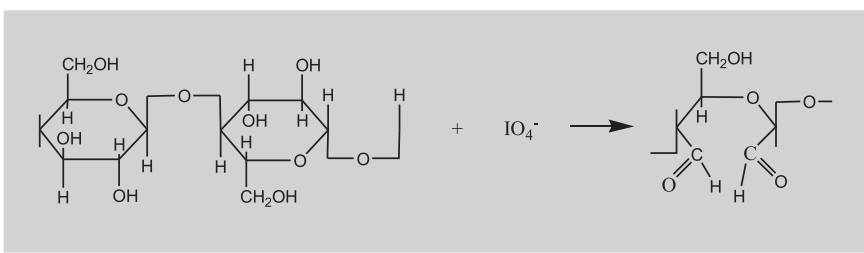

FIGURE 1 - Cellulose oxidation with periodate.

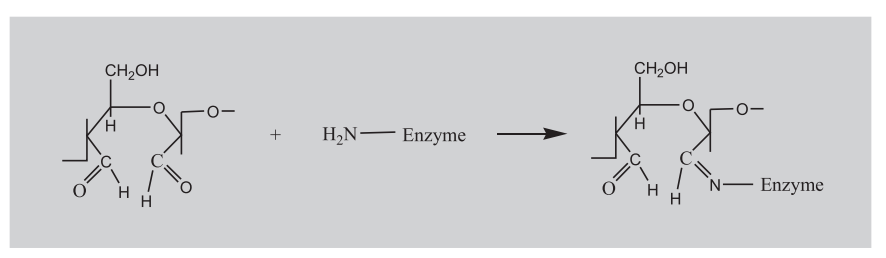

FIGURE 2 - Covalent binding of trypsin on the activated cellulose.

\section{Optimal immobilization procedure}

The effect of the trypsin solution $\mathrm{pH}$ on immobilization is presented in Figure 3. The relative activity of the immobilized trypsin was estimated as the ratio between the specific activity of the enzyme and its maximal specific activity.

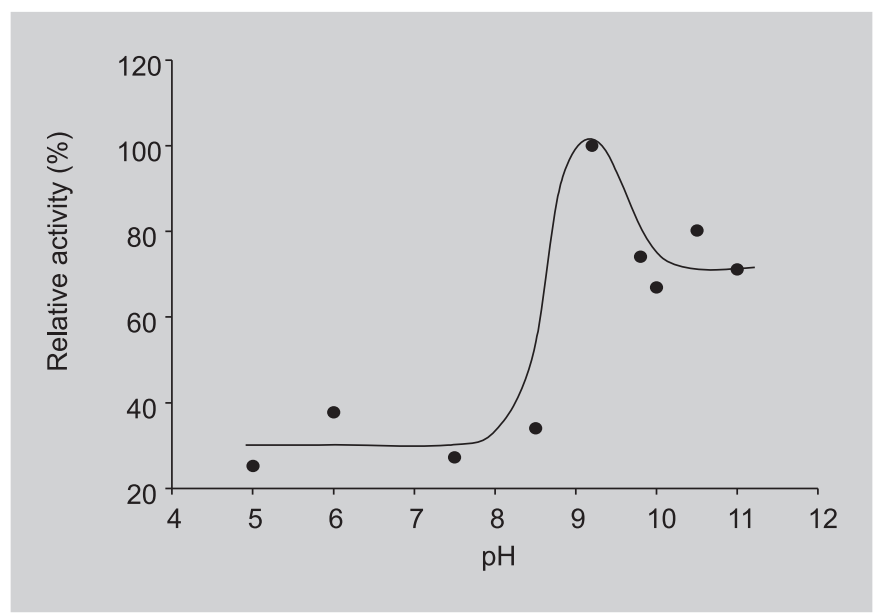

FIGURE 3 - Effect of trypsin solution pH on immobilized trypsin activity. Immobilization solution - Concentration: $3.0 \mathrm{mg} / \mathrm{mL}$; Volume: $2.5 \mathrm{~mL}$.

Higher enzymatic activities were achieved with more alkaline solutions ( $\mathrm{pH}$ between 9 and 11). This may result from the fact that a basic $\mathrm{pH}$ favoured the attachment of the enzyme in a more active conformation. A pH of 9.2 resulted in the highest activity, so it was chosen for the next assays.

By varying trypsin concentration in a buffer solution $\mathrm{pH}$ 9.2, an increase (with concentration) in specific activity was observed for trypsin solutions of concentrations below 
$0.8 \mathrm{mg} / \mathrm{mL}$ and the opposite behavior was observed for solutions of higher concentrations (Figure 4). We assume that, for higher concentrations, there were protein-protein interactions (autolysis of the trypsin) and/or distortion of the protein molecules, which resulted in its denaturation. Similar behaviour was observed by Kang et al. (2005) in the immobilization of trypsin on soap-free P(MMA-EAAA) latex particles. Thus, a $0.8 \mathrm{mg} / \mathrm{mL}$ trypsin solution was chosen to study the volume effect, which can be observed in Figure 5.

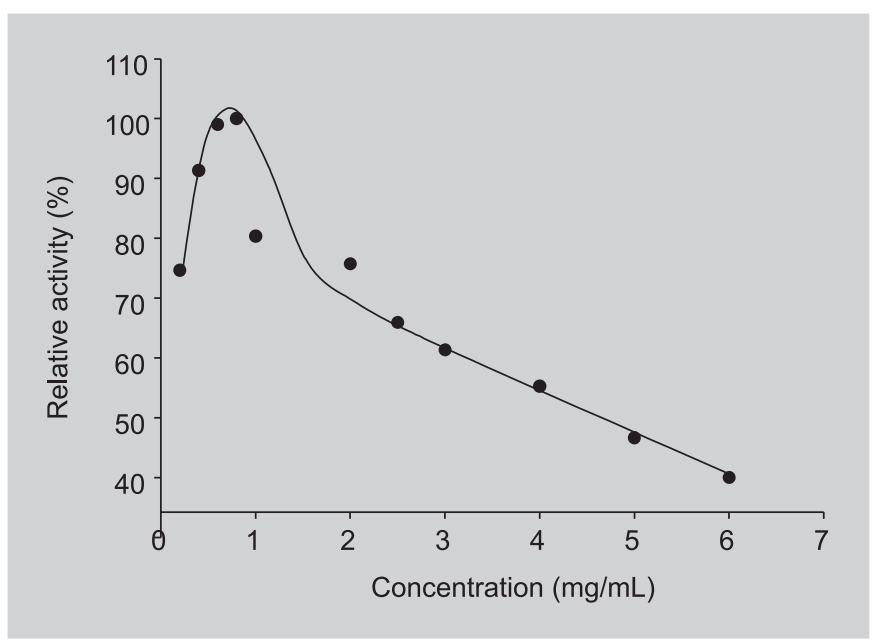

FIGURE 4 - Effect of trypsin solution concentration on immobilized trypsin activity. Immobilization solution $-\mathrm{pH}$ : 9.2; Volume: $2.5 \mathrm{~mL}$.

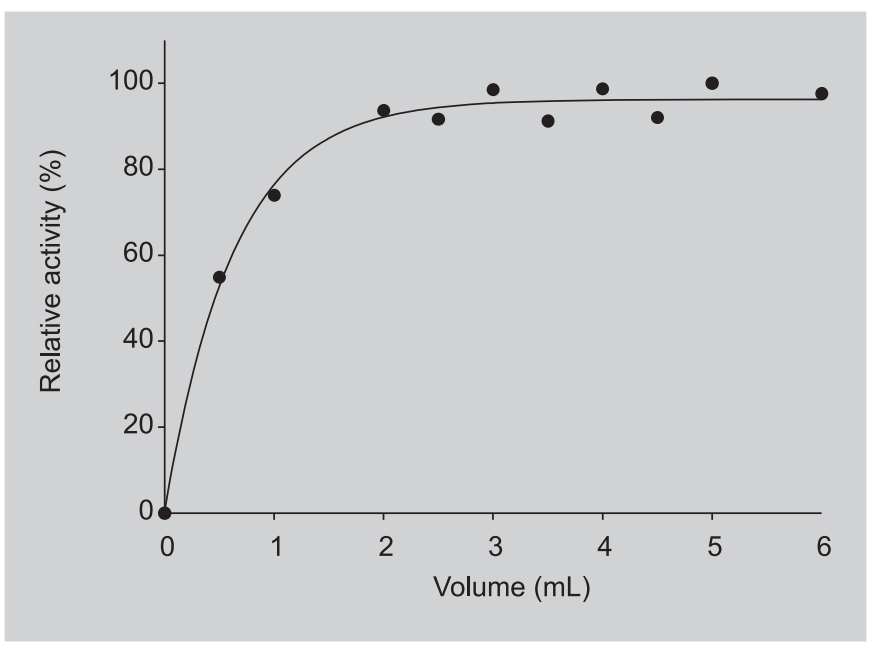

FIGURE 5 - Effect of trypsin solution volume on immobilized trypsin activity. Immobilization solution $-\mathrm{pH}$ : 9.2; Concentration: $0.8 \mathrm{mg} / \mathrm{mL}$.

The rise in catalytic activity with volume until $2.5-$ $3.0 \mathrm{~mL}$ may be attributed to a higher quantity of immobilized protein. For higher volumes, the protein molecules may have covered the support and did not allow the attachment of more molecules.

Based on these results, the optimal immobilization procedure was determined: the $5 \times 5 \mathrm{~cm}$ cotton gauze bandage piece should be immersed in $2.5 \mathrm{~mL}$ of a $0.8 \mathrm{mg} / \mathrm{mL}$ trypsin solution, prepared with buffer solution $\mathrm{pH}$ 9.2.

\section{Quantity of immobilized trypsin}

It was found that the quantity of immobilized trypsin was $6 \mathrm{mg} / \mathrm{g}$ dried support, which is of the same order of magnitude of covalently immobilized trypsin and other proteases to other materials, such as porous zirconia (Huckel et al., 1996) and a chitosan film (Akkus Centinus, Oztop, 2000), and is characteristic of supports that have low specific surface area.

\section{Physico-chemical properties of immobilized trypsin}

\section{Effect of $\mathrm{pH}$ on activity}

As shown in Figure 6, the $\mathrm{pH}$-activity profile was broader for the immobilized trypsin, which means that immobilization preserved the activity of trypsin over a wider range of $\mathrm{pH}$. This phenomenon is usually observed when enzymes are covalently coupled to supports (Kennedy, Cabral, 1987). Similar results for immobilized trypsin and other proteases have also been reported, as for example, in the immobilization of trypsin on soap-free P(MMA-EA-AA) latex particles (Kang et al., 2005) and acrylic copolymers (Bryjak, Kolarz, 1998), in the immobilization of an extracellular proteinase from Thermus strain Rt41A in pore glass beads (Wilson et al., 1994) and in the immobilization of amyloglucosidase and invertase in polyvinyl alcohol (Uhlich et al., 1996).

There was also a shift in the optimal $\mathrm{pH}$ of the immobilized enzyme to a higher value (9.5) when compared to that of the free trypsin (7.0). This shift happened because the negatively charged support increased the concentration of protons in the vicinity of the active site of the immobilized trypsin, so that the $\mathrm{pH}$ within the immobilized trypsin was lower than in the bulk solution. To counteract this effect, the optimal $\mathrm{pH}$ for enzyme activity moved to a more alkaline region (Buchert et al., 1997), which is less favourable for biomedical applications.

\section{Effect of temperature on activity}

Figure 7 shows the temperature-activity profiles. The free trypsin had an optimal temperature of $45^{\circ} \mathrm{C}$, whereas the optimal temperature of the immobilized trypsin shifted to $55^{\circ} \mathrm{C}$ (which is also less favourable for biomedical 


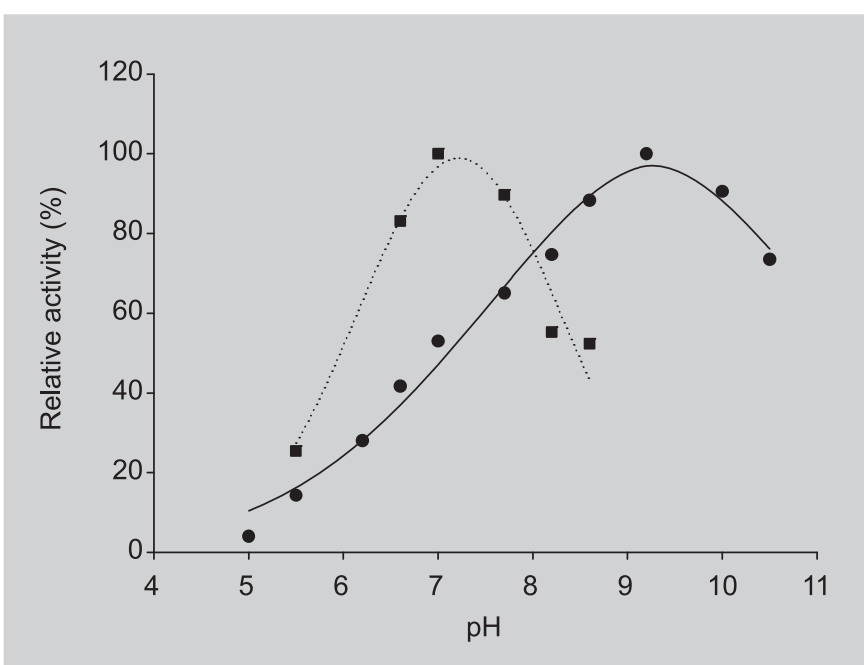

FIGURE 6 - Effect of pH on catalytic activity of free ( $\mathbf{\square})$ and immobilized $(-)$ trypsin. Reactions were performed at $37^{\circ} \mathrm{C}$ in buffers of various $\mathrm{pH}$ values.

applications). Upon immobilization, the covalent coupling of the protein molecule to the support significantly reduced its freedom to undergo the conformational changes that lead to denaturation (Arica et al., 1995; Bayramoglu et al., 2003). Similar results have been observed for trypsin and other proteases covalently immobilized to other supports like soap-free P(MMA-EA-AA) latex particles (Kang et al., 2005), a chitosan membrane (Krajewska et al., 1990) and a modified polysulphone membrane (Pozniak et al., 1995).

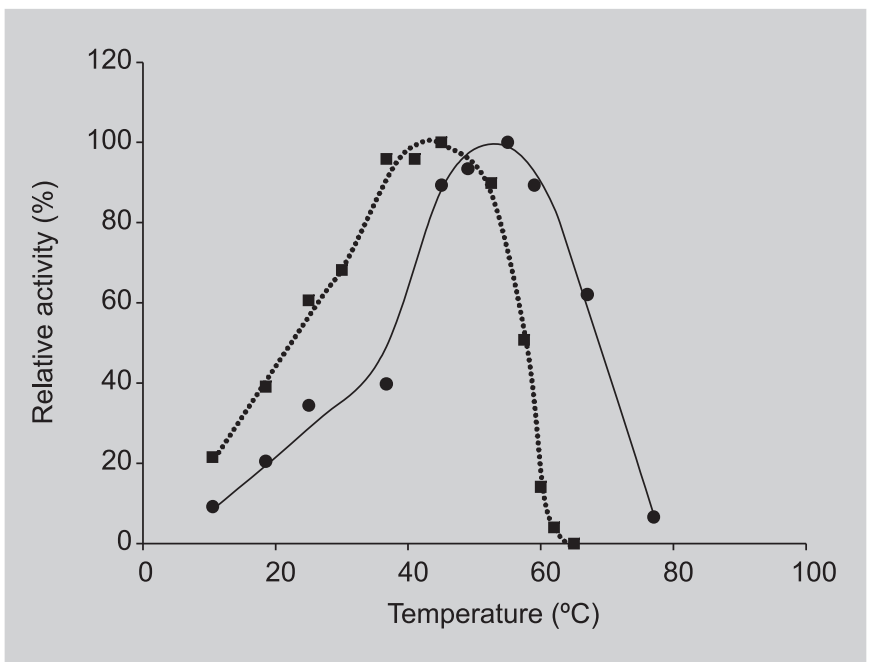

FIGURE 7 - Effect of temperature on catalytic activity of free $(\square)$ and immobilized $(\bullet)$ trypsin. Reactions were performed at various temperatures in phosphate buffer $\mathrm{pH}$ 7.0.

Kinetic parameters $\mathrm{K}_{\mathrm{M}^{\prime}} \mathrm{V}_{\max }$

The kinetic results obtained for the free and immobilized trypsin are presented in Figure 8 as Lineweaver-Burk plots, $1 / \mathrm{v}_{0}$ versus $1 /[\mathrm{S}]$. The linear nature of the Lineweaver-Burk plots proves that, in the ranges of trypsin concentration examined, both enzymes followed the Michaelis-Menten kinetics.

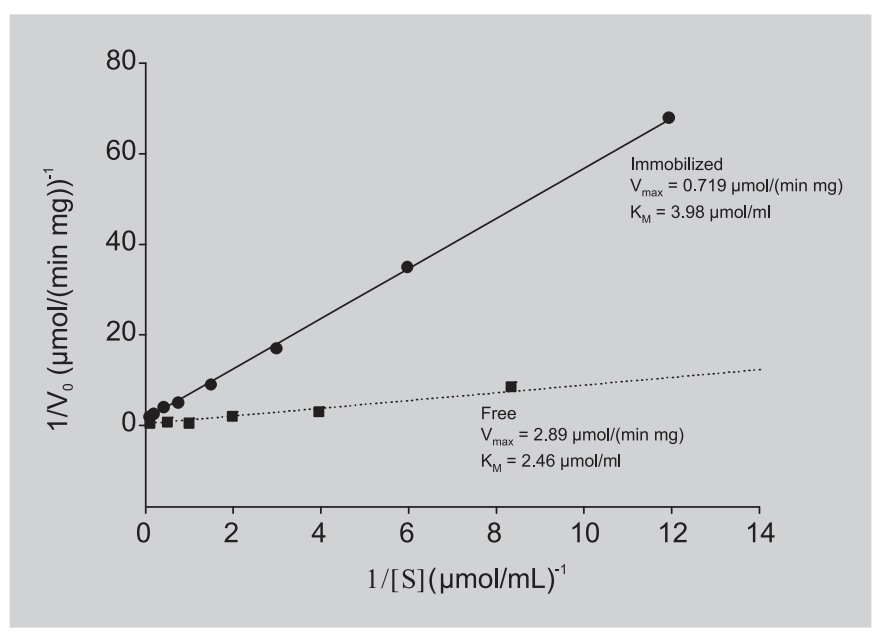

FIGURE 8 - Lineweaver-Burk plots for free ( $\boldsymbol{\square})$ and immobilized ( trypsin. Reactions were carried out in phosphate buffer $\mathrm{pH} 7.0$ at $37^{\circ} \mathrm{C}$.

The calculated values of kinetic parameters are listed in the figure. $\mathrm{K}_{\mathrm{M}}$ increased and $\mathrm{V}_{\max }$ decreased, for gauzeimmobilized trypsin, compared to its free counterpart, which indicates that the immobilized trypsin had less affinity for the substrate. However, the $\mathrm{K}_{\mathrm{M}}$ values were of the same order of magnitude. This means that the catalytic function of trypsin was not significantly impaired by the immobilization procedure. This increase in $\mathrm{K}_{\mathrm{M}}$ might has been a consequence of a lower accessibility of the substrate to the active site of the immobilized enzyme, which was caused by several factors such as protein conformational changes induced by attachment to the support, steric hindrance and diffusion effects. This increase is not very significant when compared with others observed in the immobilization of proteases in solid supports (Seifter et al., 1970).

A quite significant decrease was observed in the $\mathrm{V}_{\max }$ value after immobilization: $\mathrm{V}_{\text {max,imob }} / \mathrm{V}_{\text {max,free }}=0.25$. This is not sufficient to draw conclusions about the intrinsic activity of the immobilized trypsin, though. In fact, the activity assay was conducted at $\mathrm{pH} 7.0$ and $37^{\circ} \mathrm{C}$, which are almost the optimal $\mathrm{pH}$ and temperature of the free trypsin. At these conditions, the catalytic power of the immobilized trypsin is less than half of its maximum. If the assays were carried out in conditions closer to the optimal conditions of the immobilized trypsin, results would have been more favourable to it. However, it is natural that some 
aminoacids, essential to its catalytic activity, were involved in the covalent bonding. This happens very frequently in covalent bonding of enzymes to supports, and it is one of its main disadvantages (Klibanov, 1979).

Similar changes in the kinetic parameters of trypsin after immobilization have been reported by other researchers (Simons, Georgatsos, 1990; Zeng, Zheng, 2002; Kang et al., 2005).

\section{Trypsin leakage from the support}

The spectrophotometric assays revealed no protein in the storage solution. This result suggests that, after 30 days, the protein remained firmly attached to the support, which is characteristic of covalent immobilization of enzymes.

\section{Storage stability}

As seen in Figure 9, a $85 \%$ loss of activity was observed for free enzyme after storage for 40 days at $4{ }^{\circ} \mathrm{C}$. This might be due to protein-protein interaction (autolysis of the trypsin) (Kumar, Gupta, 1998). Gauze-immobilized trypsin lost only $15 \%$ of its activity at the same temperature in 50 days. This enhanced stability is probably a result of the prevention of autolysis by immobilization. Prevention of unfolding has played its role too.

At room temperature $\left(25^{\circ} \mathrm{C}\right)$, a $90 \%$ loss was seen after 5 days for the free enzyme, whereas the immobilized one retained $30 \%$ of its activity over 30 days.

The results mentioned above indicate that the immobilized enzyme had much better storage stability than the free enzyme. Similar results have been reported for trypsin immobilized on soap-free P(MMA-EA-AA) latex

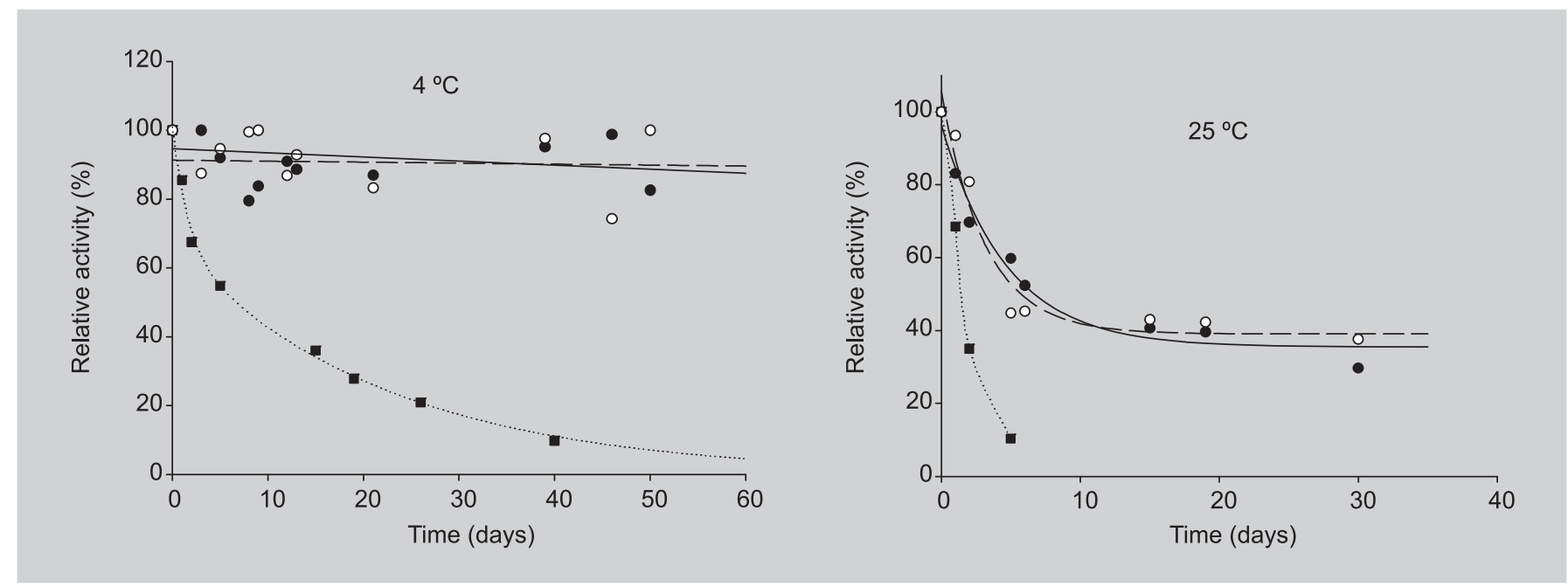

particles (Kang et al., 2005) and beads of cross-linking chitosan-coated silica gel (Xi et al., 2005).

Storage stability of the immobilized enzyme was not dependent on conditions of storage, which is typical of enzymes immobilized by strong interactions with the carrier (Kennedy, Cabral, 1987). And it was much more efficient at $4{ }^{\circ} \mathrm{C}$, which had to do with less amount of unfolding that occurred in the immobilized enzyme at a lower temperature.

\section{Reusability}

The reusability of immobilized enzymes is important for economical use of an enzyme. Immobilized trypsin retained $80 \%$ of its initial activity after being used nineteen times. Some loss of activity of the immobilized preparation in repeated use is a common phenomenon (Arasaratnam et al., 2000).

Storage conditions did not significantly influence the results, as was observed in the storage stability study.

\section{CONCLUSIONS}

In this study, trypsin was covalently immobilized on sterilized cotton gauze bandage. The physico-chemical properties of trypsin were changed after immobilization, but whilst the kinetic parameters were slightly less favourable than those of the free trypsin, the excellent storage stability and reusability demonstrate the potential of the trypsin-gauze system for practical applications. Most importantly, any enzyme with free amino groups can be successfully covalently attached to this support. Thus, cotton gauze bandage is a promising biocatalytic support. 


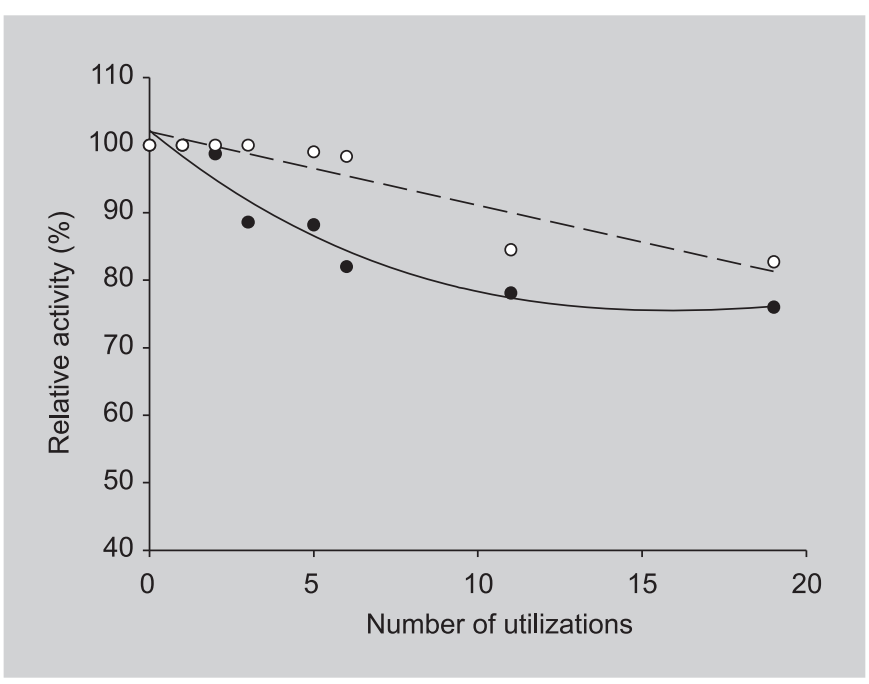

FIGURE 10 - Reusability of the immobilized trypsin, stored wet $(\mathbf{O})$ and dry $(\mathrm{O})$.

\section{RESUMO}

\section{Gaze esterilizada de algodão: suporte para a imobilização de tripsina para uso em aplicações biomédicas}

Neste trabalho foi efetuada a imobilização de tripsina numa gaze esterilizada de algodão. Foram determinadas as condições ótimas de imobilização: foi estudada a influência do $\mathrm{pH}$, concentração e volume da solução de tripsina usada na imobilização na hidrólise da N-benzoil-DL-arginina $\mathrm{p}$ nitroanilida. As propriedades catalíticas, os parâmetros cinéticos e as condições de estabilidade das enzimas livre e imobilizada foram comparadas. Os resultados mostraram que o $\mathrm{pH}$ e a temperatura ótimos para a tripsina imobilizada foram 9.5 e $55^{\circ} \mathrm{C}$, respectivamente, maiores que os correspondentes da forma livre $\left(7,5\right.$ e $\left.45^{\circ} \mathrm{C}\right)$. A $37^{\circ} \mathrm{C}$ e a $\mathrm{pH}$ 7,0 (aproximadamente as condições fisiológicas) $K_{m}$ (constante de Michaelis) foi 3,98 $\mathrm{mmol} / \mathrm{mL}$ e $V_{\max }$ (velocidade máxima de reacção) foi 0,719 $\mathrm{mol} /(\mathrm{min} \mathrm{mg}$ ) para a tripsina imobilizada; para a tripsina livre os valores corres-

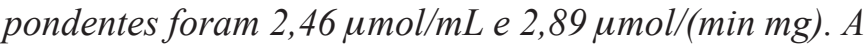
quantidade de enzima imobilizada foi de $6 \mathrm{mg} / \mathrm{g}$ (base seca). Após 30 dias não se verificou libertação de tripsina do suporte. O bom desempenho da tripsina imobilizada na gaze esterilizada de algodão comprova a sua potencial utilização como agente anti-inflamatório no tratamento de lesões cutâneas.

UNITERMOS: Gaze esterilizada de algodão. Tripsina/ imobilização. Lesões cutâneas/tratamento.

\section{REFERENCES}

AKKUS CETINUS, S.; OZTOP, H.N. Immobilization of catalase on chitosan film. Enzyme Microb. Technol., v.26, n.7, p.497-501, 2000.

ARASARATNAM, V.; GALAEY, I.Y.; MATIASSON, B. Reversibly soluble biocatalyst: optimization of trypsin coupling to Eudargit S-100 and biocatalyst activity in soluble and precipitated forms. Enzyme Microb. Technol., v.27, p.254-263, 2000.

ARICA, M.Y.; HASIRCI, V.; ALAEDDINOGLU, N. Covalent immobilization of a-amylase onto PHEMA microspheres: preparation and application to fixed bed reactor. Biomaterials, v.15, p.761-768, 1995.

BAYRAMOGLU, G.; AKGOL, S.; BULUT, A.; DENIZLIN, A.; ARICA, M.Y. Covalent immobilisation of invertase onto a reactive film composed of 2-hydroxyethyl methacrylate and glycidyl methacrylate: properties and application in a continuous flow system. Biochem. Eng. J., v.14, p.117-126, 2003.

BEDDOWS, C.G.; GIL, M.H.; GUTHRIE, J.T. Investigation of the immobilisation of bovine serum albumin, trypsin, acid phosphatase and alkaline phosphatase to poly(hydroxyethyl acrylate)-co-cellulose and poly(hydroxyethyl acrylate)-co-pectin, Polymer Bull., v.11, p.1-6, 1984.

BRYJAK, J.; KOLARZ, B.N. Immobilization of trypsin on acrylic copolymers. Process. Biochem., v.33, p.409-417, 1998.

BUCHERT, J.; TAMMINEM, T.; VIIKARI, L. Impact of the Donnan effect on the action of xylanases on fibre substrates. J. Biotechnol., v.57, p.217-222, 1997.

CARNEIRO-DA-CUNHA, M.G.; ROCHA, J.M.S.; GARCIA, F.A.P.; GIL M.H. Lipase immobilization on to polymeric membranes. Biotechnol. Technol., v.13, p.403409, 1999.

GEMEINER, P.; STEFUCA, V.; BALES, V. Biochemical engineering of biocatalysts immobilised on cellulosic materials. Enzyme Microb. Technol., v.15, p.551-566, 1993.

GIL, M.H. Immobilization of proteins, enzymes and cells onto graft copolymeric substrates. $\mathrm{PhD}$ Thesis. University of Leeds, Leeds, 1983. 
GIL, M.H.; PIEDADE, A.P.; GUTHRIE, J.T. Immobilized enzymes for biosensors. In: SALOMONE, J.C., ed. The Polymeric Materials Encyclopedia. New York: CRC Press, 1996. Vol.5, p.3190-3197.

GREEN, N.M.; NEURATH, H. The effects of divalent cations on trypsin. J. Biol. Chem., v.204, p.379-390, 1953.

HUCKEL, M.; WIRTH, H.J.; HEARN, M.T.W. Porous zirconia: a new support material for enzyme immobilization. J. Biochem. Biophys. Methods, v.31, p.165-179, 1996.

KANG, K.; KAN, C.; YEUNG, A.; LIU, D. The Properties of Covalently Immobilized Trypsin on Soap-Free P(MMAEA-AA) Latex Particles. Macromol. Biosci., v.5, p.344$351,2005$.

KENNEDY, J.F.; CABRAL, J.M.S. Enzyme immobilization. In: KENNEDY, J.F. ed. Biotechnology. Weinheim: VCH Verlagsgesellschaft mbH, 1987. Vol. 7a, p.347-404.

KLIBANOV, A.M. Enzyme Stabilization by Immobilization. Biochemistry, v.93, p.1-25, 1979.

KRAJEWSKA, B.; LESZKO, M.; ZABORSKA, W. Urease Immobilized on Chitosan Membrane: Preparation and Properties. J. Chem. Technol. Biotechnol., v.48, p.337$350,1990$.

KUMAR,A.; GUPTA, M.N. Immobilization of trypsin on an enteric polymer Eudragit S-100 for the biocatalysis of macromolecular substrate. J. Mol. Catal. B: Enzym., v.5, p.289-294, 1998.

KUNITZ, M.; NORTHROP, J.H. Isolation from beef pancreas of crystalline trypsinogen, trypsin, trypsin inhibitor, and an inhibitor trypsin compound. J. Gen. Physiol., v.19, p.991-1007, 1936.

POZNIAK, G.; KRAJEWSKA, B.; TROCHIMCZUK, W. Urease immobilized on modified polysulphone membrane: preparation and properties. Biomaterials, v.16, p.129134, 1995.
SCOTT, J.R.; ROFF, W.J. Handbook of common polymers. Cleveland: CRC Press, 1971.

SEIFTER, S.; HARPER, E.; PERLMANN, G.; LORAND, L. Collagenases. In: GOLDSTEIN, L.; PERLMANN, G.; LORAND, L., eds. Methods in Enzymology XIX. New York: Academic Press, 1970, p. 613.

SIMONS, G.; GEORGATSOS, J.G. Immobilization of barley $\beta$-glucosidase on solid supports - yields and properties. Appl. Microbiol. Biotechnol., v.33, p.51 - 53, 1990.

STEVENS, M.P. Polymer chemistry - An introduction. 2.ed. Oxford: Oxford University Press, 1990. 551 p.

UHLICH, T.; ULBRICHT, M.; TOMASCHEWSKI, G. Immobilization of enzymes in photochemically crosslinked poly(vinyl alcohol). Enzyme Microb. Technol., v.19, p.124-131, 1996.

WATANABE, S.; SHIMIZU, Y.; TERAMATSU, T.; MURACHI, T.; HINO, T. Application of immobilized enzymes for biomaterials used in surgery. Methods Enzymol., v.137, p.545-551, 1988.

WILSON, S.A.; PEEK, K.; DANIEL, R.M. Immobilization of a proteinase from the extremely thermophilic organism Thermus Rt41A. Biotechnol. Bioeng., v.43, p.225-231, 1994.

XI, F.; WU, J.; JIA, Z.; LIN, X. Preparation and characterization of trypsin immobilized on silica gel supported macroporous chitosan bead. Process. Biochem., v.40, p.2833-2840, 2005.

ZENG, J.; ZHENG, L.Y. Studies on Penicillium sp. ZDZ1 chitosanase immobilized on chitin by cross-linking reaction. Process. Biochem., v.38, p.531-535, 2002.

Recebido para publicação em 08 de dezembro de 2006. Aceito para publicação em 07 de agosto de 2007. 